\title{
THE EFFECT OF NET FOREIGN ASSETS ON SAVING RATE
}

\begin{abstract}
Observing empirical data we find that many countries try to delay the decision of increasing saving rate in order to avoid a decrease of the living standards. However the delay leads a deterioration of countries financial stability.

We present a simple theoretical model that connects between countries' saving rate and their net foreign assets. Using cross section data set of 135 countries in 2010 we estimated the econometric relation between saving rate in 2010 as dependent variable and two explanatory variables: the current account in 2010 and the aggregated current account during 1980-2010. Our findings show that industrial countries in a bad financial state tend to decrease their saving rate as external debt is larger causing to deterioration in external debt while countries with good financial state tend to increase their saving rate and the tendency increase as financial state becomes better. Only in countries with a very large external debt saving rate tends to grow. The results point that gross foreign debt will keep increasing and will worsen world financial state causing increased risk of getting into a world crisis.
\end{abstract}

Key words: foreign assets, saving rates, living standards

\section{Introduction}

Basic economic theory claims that capital will flow from countries with low marginal product of capital into countries with high marginal product (or from developed countries with high per-capita level of capital into developing countries with low per-capita level of capital).

However, according to Eswar, Raghuram, \& Arvind, (2007) stylizes facts shows that in contrast to the neoclassical theory capital is not flowing from rich to poor countries, on the contrary, in the years previous to 2007 it seems that capital makes the opposite movement. In addition one would expect flow of capital, to fastest growing developing countries, in greater intensity then to countries with low growth rate. As it turns out according to Eswar et al., these are not the facts. Particularly, China, the fastest growing developing country, runs a surplus in its current account for the previous years to 2004. During the

Nissim Ben David, Professor in the Max Stern Academic College of Emek Yezreel, Yezreel, e-mail: nissimB@yvc.ac.il

Vol. 11, No 3, 2014: 167-188 
years 2000 to 2004 high growth countries exported significant amount of capital while the low growth countries received a significant amount. Moreover, looking at the correlation between long run growth in nonindustrial countries and the current account balance they reveal a positive correlation (not negative as one would expect). The explanation the researcher offer is that poor countries do not have the financial system that can easily absorb and ramp investment up substantially. Secondly, domestic saving is growing substantially in poor countries that are growing rapidly because it takes a while until households respond in rising consumption to the rising income. Gruber and Kamin (2007) tried to explain the large surpluses in Asia's current accounts and the large deficit in U.S. current accounts in the years previous to 2007. Estimating a regression model that includes classical explanatory variables identified in the literature (per capita income, output growth, fiscal balances, net foreign assets and economic openness) they got poor regression result. After adding the financial crisis's as an explanatory variables it largely improved the explanation to the emergence of developing Asia's current account surpluses. However they failed to explain why those Asians' surpluses ended up mainly in U.S deficit rather than being spread more evenly throughout the world. Ferrucci and Miralles (2007) examined the drivers of private savings behavior in a panel of developed and developing economies. They emphasized the dynamics allowing separation between short run adjustment and long run equilibrium markets. The researchers estimated the short run private saving rate compared with that of the long term in emerging economies and in developed economies. The results shows that private saving rate in the short run, in emerging economies, shifted up from the long run equilibrium, particularly in Asia. The researchers relate this short run movement to demographic factors and financial catching-up. Moreover, they suggested that looking ahead and adjusting to long run will cause a considerable fall in saving in those countries and that further progress in financial deepening will smooth saving rate among countries in the global economy. In developed countries, however, private saving in the short run is bellow long run equilibrium Chinn and Ito (2008) investigated the factors influencing current account and saving rate with an aim to explain the world saving glut. They found that government budget balances play an important role in the determination of current account balances. Sun (2011) examined empirically the differences of private savings in developing countries and its impact on current account balances. He found that economic growth is accompanied with structural changes in productivity and in job reallocations, which in turn affect private savings. According to Sun, different growth patterns of economic sectors create new income and employment distributions. High productivity creates large wage variation across industries and sectors therefore raises saving, while faster employment growth moves labor from low income sectors to high income sectors therefore reduce saving. 
Apart from the papers mentioned above, the existing literature suggested many factors that might explain the level of savings, among them: financial development, demographic differences and the pension system (see Masson, Bayoumi and Samiei (1998), Loayza, Schmidt-Hebbel and Serven (2000).

We suppose that the changes in countries' saving rates are the most dominant factors in determining current accounts and that getting into financial instability might be a signal for policy makers to take steps in order to stabilize the economy. Our aim in this paper is to examine the effect of financial stability determined by aggregated level of current accounts in past 30 years and current account in present period on saving rate of 135 developed and developing countries.

The paper is organized in the following manner. A theoretical analysis of how current account effect steady state equilibrium within a Solow's' model is laid down in section II. An empirical estimation of the relation between saving rate and financial stability indicators is presented in section III. Section IV presents the summary.

\section{Theoretical analysis}

According to Solow (1956) the condition for long term steady state growth equilibrium is:

$$
s Y=(n+d) k,
$$

For: $\mathrm{s}$ - saving rate,

$Y=f(k)$ - per capita production,

$\mathrm{d}$ - depreciation rate and

$\mathrm{k}$ - Per capita amount of capital.

When the economy is open to trade and to capital movements, we get that in equilibrium:-

(2) $\quad I=S+I M-E X$

For: I - Total net investment,

S - Total savings,

EX - Total export and

IM - Total import.

Let us define: $S_{n e t}=S+M-\mathbb{X}$ and:

(3) $\quad s_{n e t}=\frac{S+I M-E X}{Y}$

$S_{\text {net }}$ - represent net saving rate in open economy. 
In open economy equilibrium condition will be changed into:

$$
s_{n e t} Y=(n+d) k \text {. }
$$

In order to present the effect of opening economies to trade and to capital movements, let us consider 2 countries with equal production function, equal population growth rate and equal depreciation rate. The only factor differentiating the countries is saving rate which is assumed to be higher in country 2 .

Figure 1: Presents long term equilibrium for each of the countries for economies that are closed to capital movements and to trade.

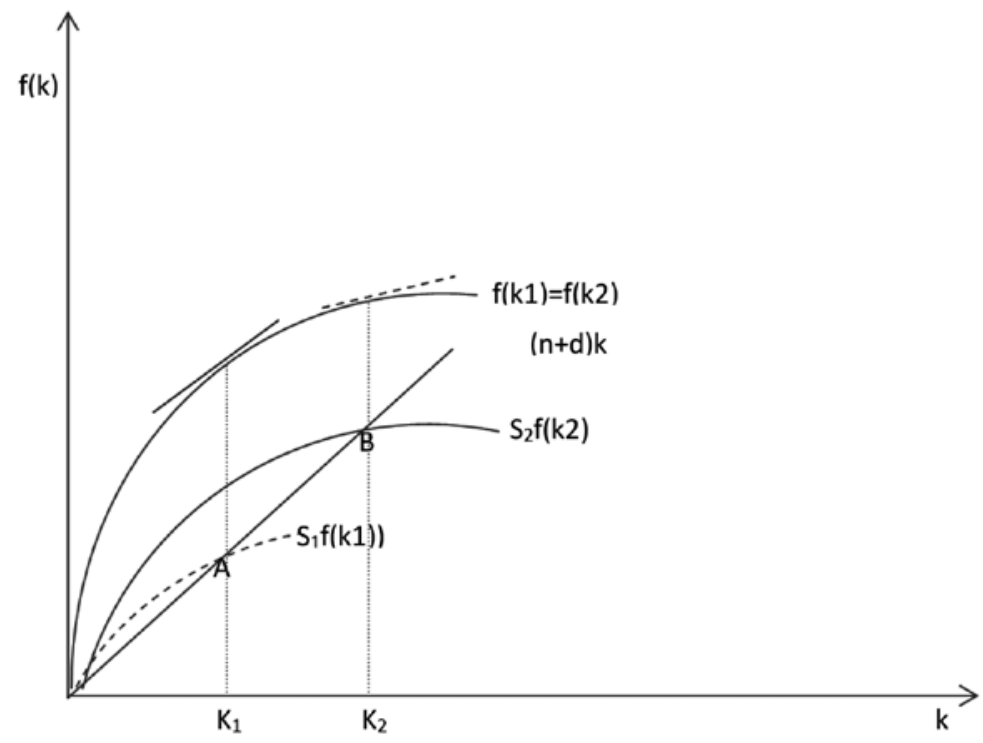

The dashed line represents the saving curve of the country with the lower saving rate.

Equilibrium of capital per-capita is lower in country 1 and marginal product of capital is higher - $f^{\prime}\left(k_{2}\right)<f^{\prime}\left(k_{1}\right)$ (see red line slope).

When economies are open to capital and goods movements, we expect that capital will flow from country 2 into country 1 and will seas flowing when marginal production in both countries will be equal. 
The new equilibrium is depicted in figure 2 below:

Figure 2: New equilibrium

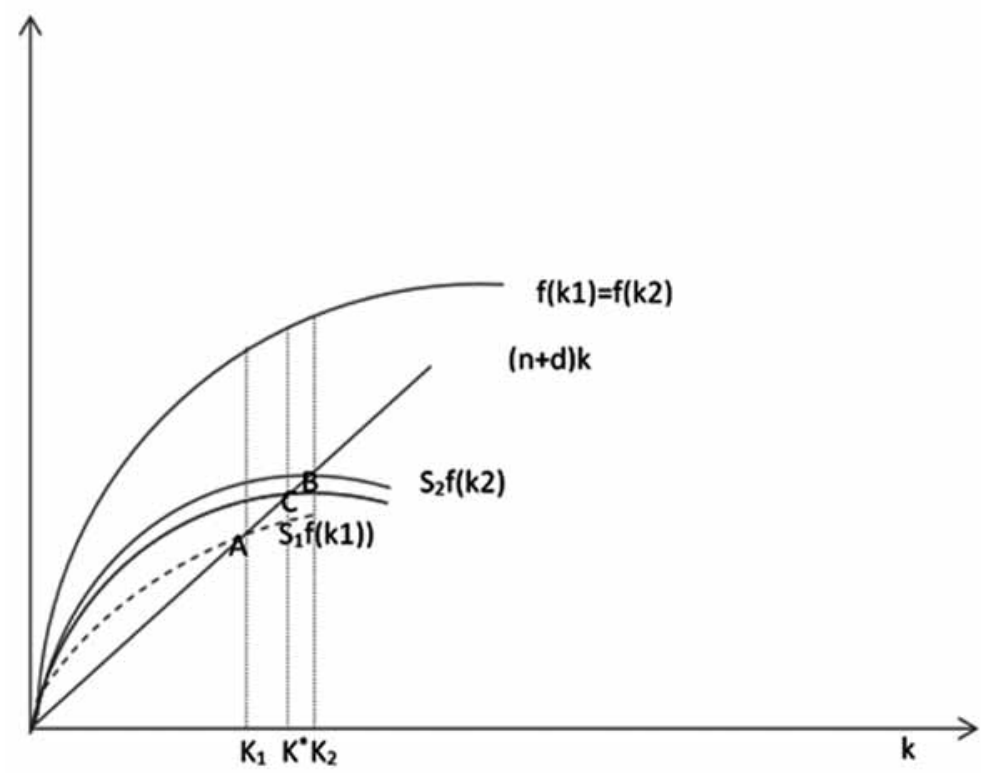

Both economies will converge to point $\mathrm{C}$ with equal long run capital - $\mathrm{K}^{*}$ and equal product per-capita.

We should notice that country 1 will have negative trade balance while country 2 will have positive trade balance. Given that each country persist with the same savings rate, population growth, depreciation rate and production function, the net deficit in foreign asset of country 1 and the net positive foreign asset of country 2 will persist to grow.

\section{What will stop foreign debt from growing?}

When the foreign debt grows, countries' financial state is perceived as more dangerous by other countries. At the first stage interest rate on foreign loans rise, a process that might increase local savings while decreasing local investment, causing improvement in trade balance and slowing the growth rate of foreign debt. In some countries the rise of interest rate might not stop local consumption and the deterioration of countries financial state. Under such conditions, foreign global organizations such as the „world bank”," international monetary fund” or other institutions or friendly governments will suggest financial aid that generally include a new proper economic program for decreasing local consumption while increasing local savings.

If the process described above characterize reality we expect that as long as foreign debt is low, a country has the freedom of decreasing savings without 
decreasing private consumption and net investment. However, when foreign debt increases above a given threshold, the country will be perceived as financially instable and will be expected to increase savings while decreasing consumption and investment. Local saving rate is expected to be determined as a positive function of countries' external debt per capita.

\section{The connection between external debt and the saving rate}

If a country that has a large external debt accompanied by trade balance deficit starts increasing saving rate it can move to an acceptable level of external debt per capita. Given that the country is initially at point $C$ (figure 2), capital and production per capita should not change following the increase in gross savings, however consumption should be reduced, trade balance will improve and investment stay constant.

Reduction in net investment might occur when a country is perceived as financially more dangerous. Higher risk pushes the local interest rate up leading to higher marginal product of capital and lower amount of capital per capita.

Figure 3 and figure 4 present a country with initial long term equilibrium of capital per capita in point $C$. Savings rate, $S_{1}$, determines a large negative trade balance and high consumption level ( $\mathrm{CONS}_{1}$ ).

The country can persist with the low saving rate as long as external debt is at an acceptable level.

However, when the external debt is crossing a given level, the country is forced to increase saving rate (see figure 4). The increase in savings is accompanied with consumption reduction to Cons ${ }_{1}^{1}$ (see figure 3 ).

Figure 3: The increase in savings accompanied with consumption reduction

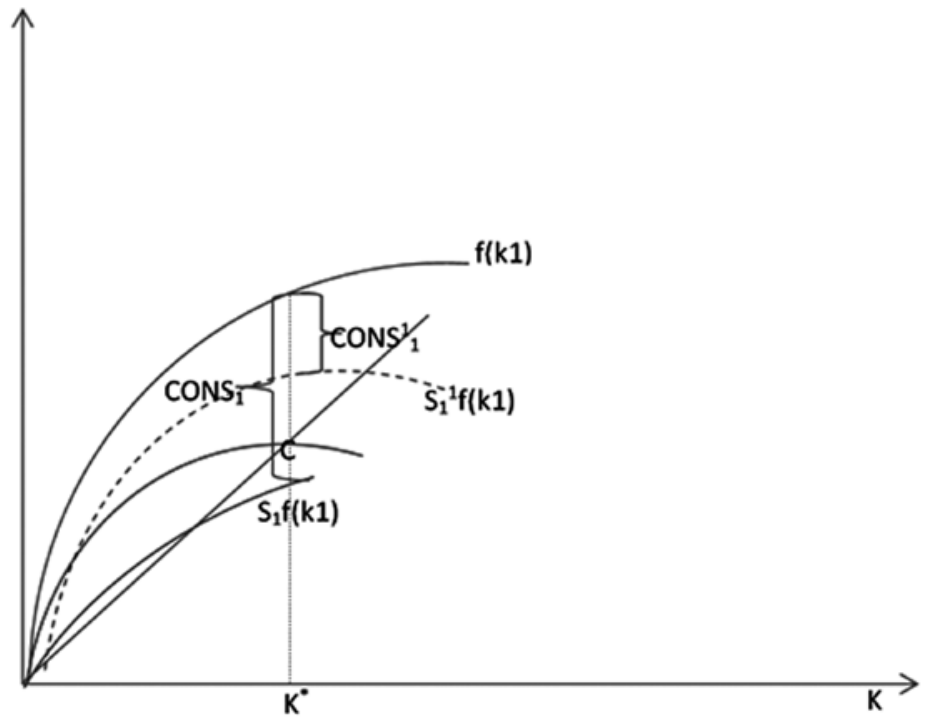


Figure 4: The external debt crossing a given level - the country forced to increase saving rate

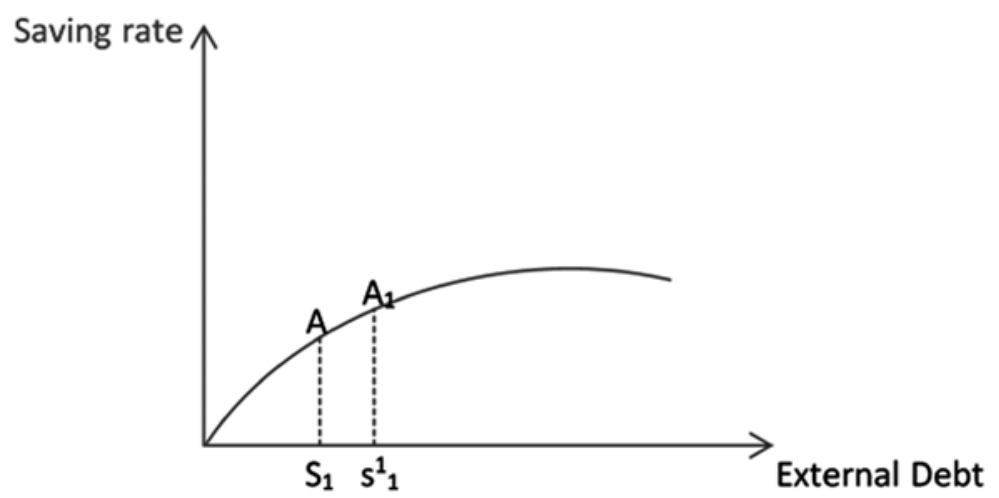

\section{Should a country create external debt?}

A country with a low saving rate reaches a low equilibrium level of capital when trade balance is balanced. Starting at point A in figure 1 the country can move instantly to point $C$ by creating a trade balance deficit. In point $C$ capital level, production and private consumption grow, together with foreign debt. As long as foreign debt is low, gross saving rate can persist to be low.

However as foreign debt crosses a given threshold, the country is forced to increase its gross saving rate and reduce consumption.

One can think of situations where creation of a large external debt is worthy, especially if the debtors agree to give up some of the debt as part of a rescue plan that include decrease in consumption and increased savings in the borrowing country.

\section{How should we define countries' financial state?}

At first, we thought that the most obvious variable to represent financial risk is net foreign assets. However after examining data published by the „world bank" we were surprised to reveal that the aggregate net foreign assets of all countries sum into a huge amount of over 13,000 billion American dollars in 2010. This contradicts the common knowledge that aggregate net foreign assets of all countries must be summed to zero, since a positive net foreign asset in one country should be accompanied by a negative net foreign asset of the same amount in other countries. It is well known that such odd results occur when definitions of variables according to statistical agencies that are responsible for collecting the data differ from classical economic definitions. Since worlds bank definition of foreign net assets do not include investment in real estate assets abroad or other capital movement, we get that aggregate net foreign assets differ largely from zero. 
In figure 5 we depicted the connection between gross saving rate and the net foreign assets rate (from GDP) for 135 countries in 2010.

Figure 5: Saving rate and the foreign assets rate

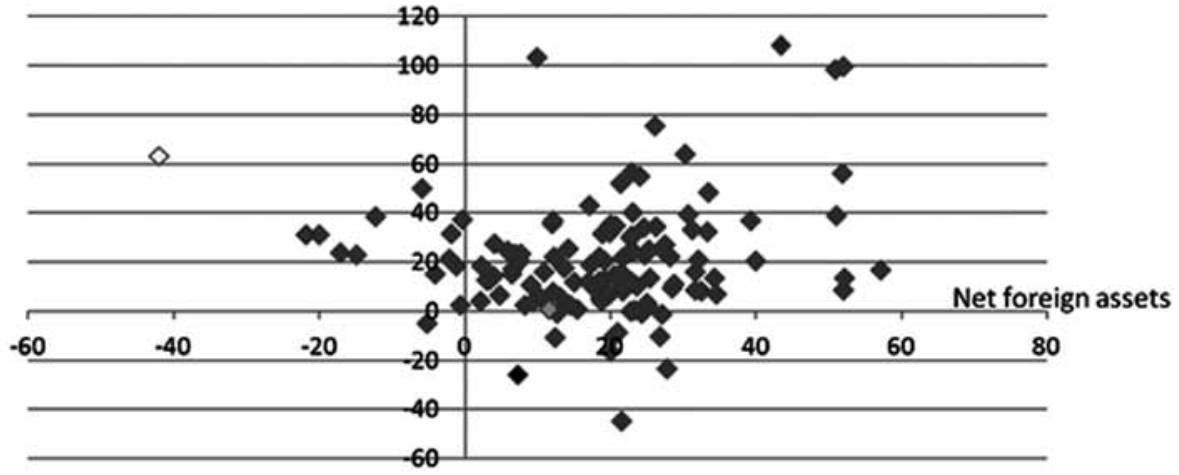

Legend: Yellow: Lesoto; Red: Afganistan; Green: U.S.A; Purple: South Arabia; Black: Greece; Gray: Portugal

We can see that for a vast majority of the countries, net foreign assets rate is positive and only in 13 out of 135 countries it is negative (See in appendix 2 the gross saving rate and net foreign assets rate for all 135 countries). We do not intend to get here into an argument of why world bank data on net foreign assets do not represent countries financial risk, but preffer to search for a better risk indicator.

\section{Alternative indicator for financial stability}

If we would measure correctly all capital movements in each year, net foreign assets in period $t$ should equal to the aggregated current accounts that starts in period 0 and ends at period t.

Equation (5) defines the connection between net foreign assets and current account.

$$
\text { (5) } \quad N F T_{T}=N F T_{0}+\sum_{t=1}^{T} C A_{t}
$$

For:

$N F_{t}$ - net foreign asset in period $\mathrm{t}$

$C A_{t-}^{t}$ Current account in period $\mathrm{t}$.

We can see that aggregation of current account for a long enough period of time can be a good indicator for the total net foreign assets of a country.

Using IMF data of Current account ratio to GDP (CA ratio) we calculated for each country the aggregated CA ratios for the period 1980-2010. 
Figure 6 presents the connection between aggregated Current account ratio DURING 1980-2010 and Gross Savings ratio to GDP in 2010 (see data in appen$\operatorname{dix} 1)$.

Figure 6: Saving rate in 2010 and agrregate current acount in 1980-2010.

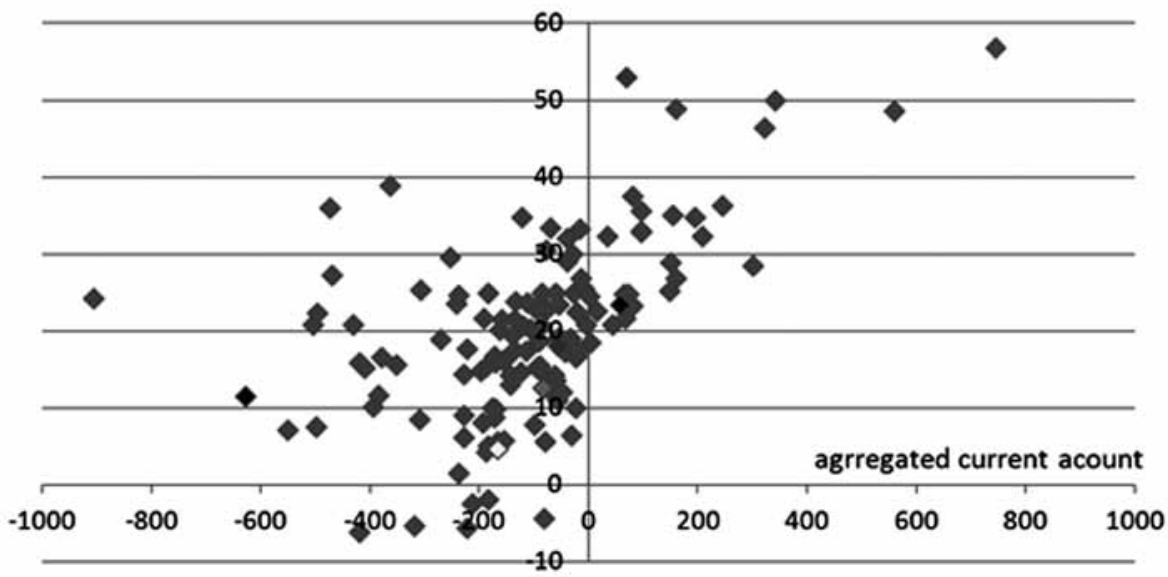

Legend: Greece: yellow; Germany: black; China: red; Brazil: purple; U.S.A: Green; Katar: gray; Nicaragua: brown

We can see that according to figure 6 worlds' countries aggregated current account is distributed as expected, with many countries having a negative aggregated CA ratio.

\section{Empirical model}

In this part we estimated an econometric equation with saving rate as dependent variable and two explanatory variables defining countries' financial risk: the current account and the aggregated current account.

(6) savings $=\alpha_{1} D_{1}+\alpha_{2} D_{2}+\alpha_{3} D_{3}+\beta_{1} A G C U R * D_{1}+\beta_{2} A G C U R * D_{2}$

$+\beta_{3} A G C U R * D_{3}+\delta_{1} A G C U R^{2} * D_{1}+\delta_{2} A G C U R^{2} * D_{2}+\delta_{3} A G C U R^{2} * D_{3}$

$+\gamma_{1} * C U R 2010 * D_{1}+\gamma_{2} * C U R 2010 * D_{2}+\gamma_{3} * C U R 2010 * D_{3}+u$

For:

Savings - saving rate ratio in 2010.

AGCURR - aggregated CA ratio in years 1980-2010.

CURR2010 - Current account in 2010. 
D1 - a dummy variable equal to 1 for 45 countries with the lowest aggregate current account in years 1980-2010.

D2 - a dummy variable equal to 1 for 45 countries with middle aggregate current account in years 1980-2010.

D3 - a dummy variable equal to 1 for 45 countries with the highest aggregate current account in years 1980-2010.

Table 1: Results of the regression after correcting for Heteroskedasticity and removing non-significant variables

\begin{tabular}{|c|c|c|}
\hline Significant level & Coefficient & Variable \\
\hline 0.0000 & 15.66787 & D1 \\
\hline 0.0000 & 28.20771 & D2 \\
\hline 0.0000 & 22.69293 & D3 \\
\hline 0.0119 & -0.024005 & CURRENT*D1 \\
\hline 0.0007 & 0.027577 & CURRENT*D3 \\
\hline 0.0066 & -0.000255 & CURRENT^ $2^{*}{ }^{*} 2$ \\
\hline 0.0000 & 0.727978 & CURR2010*D1 \\
\hline 0.0000 & 1.131170 & CURR2010*D2 \\
\hline 0.0000 & 1.013667 & CURR2010*D3 \\
\hline 0.0022 & -0.020227 & CURR2010^2*D3 \\
\hline
\end{tabular}

The estimated equations are as follows:

for countries with a very large negative aggregated current account:

$$
\text { savings }^{f}=15.66787-0.024005 * \mathrm{AGCURRENT}+0.727978 * \text { CURR2010 }
$$

For countries with large or medium negative aggregated current account (in absolute values):

$$
\begin{aligned}
\text { savings }^{f}= & 28.20771-0.000255 * \mathrm{AGCURRENT} \\
& +1.131170 * \text { CURR } 2010
\end{aligned}
$$

For countries with a small negative or with positive aggregated current account:

$$
\begin{aligned}
\text { savings }^{f}= & 22.69293+0.027577 * \mathrm{AGCURRENT}+ \\
& 1.013667 * \text { CURR2010 }-0.020227 * \text { CURR } 2010^{2}
\end{aligned}
$$

Notice that we can interpret the coefficients of dummy variables as basic saving rates. 
We get that countries with very large negative aggregate current account (in the lower edge Equatorial Guinea with $-907.35 \%$ aggregated CA and in the upper edge Portugal $-170.49 \%$ aggregated CA) saving rate increases in a larger amount as aggregate current account is more negative (see equation 7 -negative coefficient multiplied by negative aggregated current account).

For countries with large and medium aggregated negative account (in the lower edge Costa Rika with $-170.14 \%$ aggregated CA and in the upper edge El Salvador $-55 \%$ aggregated CA) saving rate decreases in larger amount as aggregate CA is more negative (see equation 8 - negative coefficient multiplied by squared aggregated CA). Among this group we can find several industrial countries with negative aggregated CA, Greece with $-166 \%$, Poland with $-155 \%$, Australia $-133 \%$, Spain with $-92 \%$, U.S.A. with $-82 \%$, Ireland with $-60 \%$ and other large economies such as, Turkey $-59 \%$ and Brazil $-56 \%$.

In countries with relatively small negative aggregated current account (in the lower edge Mexico with $-54 \%$ aggregated CA) saving rate decreases in larger amount as aggregate $\mathrm{CA}$ is more negative (see equation 9 - positive coefficient multiplied by negative aggregated CA). Among this group we can find several industrial countries with negative aggregated CA, United Kingdom -48\%, Canada $-32 \%$, Italy $-21 \%$ and other large economies such as India $-38 \%$ and South Africa $-24 \%$.

Countries with positive aggregate current account (see equation $9^{1}$ ) tend to increase the saving rate in a larger amount as aggregated net foreign account is more positive. Among this group we can find Austria 1.8\%, France 3.37\%, Korea $33 \%$, Germany $57 \%$, Japan $80 \%$ and China $208 \%$.

Current year current account have a negative effect on saving rate in all countries with negative aggregated current account, while in countries with positive current account the effect is positive but diminishes as current account is growing.

These results point that countries with negative medium or small aggregate current account will tend to „sink” deeper. In addition in these countries saving rate will decrease when current year current account is negative.

The results are troubling since this group includes some of the major worlds' economies, such as U.S.A, Australia, Spain, Turkey, Brazil, United Kingdom, Canada, Italy, India and South Africa.

Countries with positive aggregate current account (external assets) will tend to increase saving rate. In addition positive current year current account will increase saving rate even higher.

Our interpretation of the results is that countries' will tend to go to the edge, those with positive net foreign assets will keep increasing their assets while those

Equation 9 was estimated on data of countries with small aggregated negative CA and on data of countries with positive aggregated CA. 
with external debt will tend to increase debt as long as the debt is not very large. Only when external debt becomes very large, saving rate will start growing.

Since some of the largest economies belong to the group that keep increasing external debt due to continues reduction of the saving rate, we are concerned of the obvious conclusion that at some stage when debt will become too large, the world will go into a deep financial crisis.

We should mention that countries which have a middle level of aggregate current account have a higher basic saving rate $28.20771 \%$, in comparison to the counties at the edges. Since most of the western countries can be classified as "middle countries”, world institutions should concentrate at these counties which produce a major part of world production.

\section{Summary}

We presented a theoretical analysis of an economy that is open to international trade and to capital movements by using Solow's model (1956) as a frame. According to our analysis, a country can accelerate the convergence to long run steady state of per-capita production and capital by creating a negative current account and creating external debt. As long as the country is financially stable, it can keep a low saving rate and high consumption per-capita. However when external debt increases beyond acceptable level the country will not be able to borrow from abroad and will be forced to increase saving rate and improve current account, a process that will cause a reduction of external debt.

In the empirical part of the paper we suggest to measure financial stability of a country by the aggregated current account in the last 31 years (1980-2010). We think that this measure is better than the "net foreign assets” which does not include all financial factors that define countries' financial stability.

Using data of 135 countries we estimated a cross section econometric equation with saving rate as dependent variable and the current account and aggregated current account as explanatory variables.

Our findings show that countries with very high external debt tend to increase their saving rate, while countries with medium or low external debt tend to reduce their saving rate. The group of countries with medium and low external debt includes many of the most developed countries, among them U.S.A, United Kingdom and span.

Countries with positive aggregated current account tend to increase their saving rate as their aggregate CA is larger.

Our findings are troubling since they show that countries which are at the edge of becoming unstable financially tend to deteriorate into a worse financial state and only when financial state becomes extremely unstable they start incre- 
asing saving rate. It seems that if this behavior will proceed, the world might fall into a deep crisis.

The finding point to the fact that deterioration of worlds' financial stability is due to the negative financial state of some of the most dominant and productive countries.

We believe that in order to stop deterioration, worlds' organization together with worlds' leading countries must concentrate on economic policy that will create a change in the most developed countries which carry medium levels of external debt, but can risk all worlds' financial system.

\section{Literature}

- Chin, D.M. and Ito, H. (2008): „Global Current Account Imbalances: American Fiscal Policy versus East Asian Savings „, Review of International Economics, 2008, 16(3),pp. 479-498.

- $\quad$ Eswar, P., Raghuram, R. and A.Subramanian, A. (2007): "Foreign Capital and Economic Growth", Brookings Papers on Economic Activity, 2007, 1, pp. 153-230

- Ferucci, G. and Miralles, C: (2007): "Saving Behaviour and Global Imbalances The Role of Emerging Market Economies”, European Central Bank Working Paper Series No 842/ December 2007.

- Gruber, W.G. and Kamin, S.B.,(2007): "Explaining the global pattern of currentaccount imbalances", Journal of International Money and Finance 26 ,(2007), pp. 500-522.

- Loayza, N., Schmidt-Hebbel, K. and Serven, L. (2000):"What Drives Private Saving Across the World?", The Review of Economics and Statistics No 82(2), May pp. 165-181.

- Masson, P.R., Bayoumi, T. and Samiei, H. (1998):"International Evidence on tha Determinants of Private Saving", The World Bank Economic Review, No 12 (3) , pp 483-501.

- Solow, R.M. (1956). "A Contribution to the Theory of Economic Growth," Quarterly Journal of Economics 70, pp.65-94.

- Sun. Y (2011): "Structural Change, Savings and Current Account Balance", International Review of Economics and Finance 20 (2011) pp 82-94. 


\section{Appendix 1}

Gross savings rate, Aggregated current accounts during 1980-2010 and current account in 2010 as percentage of GDP in 2010

\begin{tabular}{|c|c|c|c|}
\hline & saving rate 2010 & agg current acount & curr2010 \\
\hline Equatorial Guinea & 24.322 & -907.35 & -24.07 \\
\hline Nicaragua & 11.428 & -627.597 & -14.372 \\
\hline Guyana & 7.256 & -551.104 & -9.513 \\
\hline Sudan & 20.856 & -505.463 & 0.717 \\
\hline Dominica & 7.584 & -497.839 & -21.138 \\
\hline Lebanon & 22.34 & -496.546 & -10.822 \\
\hline Bhutan & 36.122 & -473.022 & -11.64 \\
\hline St. Kitts and Nevis & 27.358 & -469.999 & -20.642 \\
\hline St. Lucia & 20.901 & -431.27 & -15.203 \\
\hline Antigua and Barbuda & 15.945 & -419.492 & -12.945 \\
\hline St. Vincent and the Grenadines & -6.104 & -419.284 & -31.571 \\
\hline Lesotho & 15.334 & -408.95 & -15.084 \\
\hline Mozambique & 10.258 & -393.509 & -11.742 \\
\hline Togo & 11.688 & -384.834 & -7.125 \\
\hline Seychelles & 16.604 & -378.343 & -20.08 \\
\hline Chad & 38.896 & -363.427 & -3.51 \\
\hline Mauritania & 15.688 & -351.676 & -8.802 \\
\hline Grenada & -5.209 & -318.245 & -25.529 \\
\hline Comoros & 8.542 & -308.475 & -6.863 \\
\hline Cape Verde & 25.337 & -308.34 & -12.467 \\
\hline Madagascar & 18.928 & -269.929 & -9.679 \\
\hline Zambia & 29.635 & -253.099 & 7.068 \\
\hline Senegal & 23.613 & -241.555 & -6.095 \\
\hline Malawi & 24.78 & -238.617 & -1.246 \\
\hline Guinea-Bissau & 1.564 & -238.578 & -8.253 \\
\hline Benin & 9.122 & -228.784 & -7.192 \\
\hline Sierra Leone & 6.288 & -227.605 & -28.772 \\
\hline Jamaica & 14.401 & -227.484 & -8.097 \\
\hline Niger & 17.729 & -222.562 & -21.103 \\
\hline Solomon Islands & -5.557 & -222.301 & -30.259 \\
\hline
\end{tabular}


The effect of net foreign assets on saving rate

\begin{tabular}{|c|c|c|c|}
\hline Maldives & -2.356 & -212.812 & -17.356 \\
\hline Belize & 14.923 & -197.954 & -3.076 \\
\hline Burundi & 8.114 & -192.969 & -9.889 \\
\hline Tanzania & 21.638 & -191.506 & -9.278 \\
\hline Iceland & 4.256 & -188.22 & -8.389 \\
\hline Burkina Faso & 15.391 & -188.179 & -3.567 \\
\hline Guinea & -1.785 & -184.451 & -12.351 \\
\hline Central African Republic & 5.126 & -183.915 & -9.939 \\
\hline Sri Lanka & 24.956 & -183.61 & -2.196 \\
\hline The Bahamas & 10.028 & -176.78 & -11.689 \\
\hline Cyprus & 8.894 & -172.788 & -9.876 \\
\hline Honduras & 16.734 & -171.665 & -6.222 \\
\hline Rwanda & 15.889 & -171.223 & -5.978 \\
\hline Portugal & 9.945 & -170.496 & -9.981 \\
\hline Costa Rica & 16.575 & -170.141 & -3.518 \\
\hline Greece & 4.574 & -166.387 & -9.982 \\
\hline The Gambia & 5.688 & -166.319 & -15.736 \\
\hline Democratic Republic of Congo & 20.163 & -163.372 & -6.906 \\
\hline Bulgaria & 21.568 & -157.963 & -1.322 \\
\hline New Zealand & 16.162 & -156.481 & -3.432 \\
\hline Poland & 16.293 & -155.772 & -4.66 \\
\hline Mali & 5.796 & -154.718 & -12.628 \\
\hline Guatemala & 13.123 & -143.746 & -1.52 \\
\hline Albania & 14.272 & -143.393 & -11.614 \\
\hline Hungary & 19.498 & -138.638 & 1.097 \\
\hline Jordan & 17.567 & -135.765 & -5.574 \\
\hline Tunisia & 21.587 & -134.708 & -4.796 \\
\hline Australia & 23.943 & -133.037 & -2.844 \\
\hline Uganda & 14.679 & -123.029 & -9.569 \\
\hline Vietnam & 34.904 & -122.189 & -4.139 \\
\hline Suriname & 20.761 & -120.618 & 2.035 \\
\hline Ghana & 17.413 & -113.456 & -7.302 \\
\hline Peru & 23.687 & -112.27 & -1.707 \\
\hline Romania & 20.387 & -106.355 & -4.452 \\
\hline Dominican Republic & 7.91 & -98.466 & -8.59 \\
\hline Haiti & 22.877 & -96.179 & -2.556 \\
\hline
\end{tabular}


Nissim Ben David

\begin{tabular}{|c|c|c|c|}
\hline Panama & 15.213 & -94.885 & -10.763 \\
\hline Spain & 18.698 & -92.025 & -4.604 \\
\hline Mauritius & 15.59 & -88.585 & -8.158 \\
\hline Angola & 23.047 & -87.913 & 10.378 \\
\hline Kenya & 14.912 & -87.707 & -6.525 \\
\hline Ethiopia & 20.716 & -86.093 & -4.35 \\
\hline Chile & 25.039 & -84.378 & 1.512 \\
\hline United States & 12.532 & -82.639 & -3.242 \\
\hline Swaziland & -4.251 & -81.869 & -16.483 \\
\hline Barbados & 5.637 & -78.506 & -8.204 \\
\hline Morocco & 30.557 & -77.107 & -4.234 \\
\hline Ecuador & 22.87 & -75.423 & -3.307 \\
\hline Pakistan & 13.134 & -74.834 & -2.231 \\
\hline Nepal & 33.413 & -69.031 & -2.406 \\
\hline Cameroon & 13.288 & -64.014 & -2.835 \\
\hline Paraguay & 14.367 & -61.397 & -3.378 \\
\hline Bolivia & 24.987 & -60.706 & 4.89 \\
\hline Ireland & 11.528 & -60.036 & 0.488 \\
\hline Turkey & 13.581 & -59.51 & -6.35 \\
\hline Brazil & 18.03 & -56.479 & -2.208 \\
\hline Colombia & 19.109 & -55.731 & -3.083 \\
\hline El Salvador & 10.991 & -55.354 & -2.301 \\
\hline Mexico & 23.541 & -54.397 & -0.299 \\
\hline United Kingdom & 12.058 & -48.319 & -3.318 \\
\hline Uruguay & 17.37 & -43.536 & -1.184 \\
\hline Israel & 18.879 & -39.812 & 2.914 \\
\hline Bangladesh & 29.157 & -38.894 & 1.664 \\
\hline India & 32.144 & -38.517 & -3.268 \\
\hline Canada & 19.072 & -32.5 & -3.131 \\
\hline Papua New Guinea & 6.504 & -31.687 & -8.442 \\
\hline Thailand & 30.067 & -28.482 & 4.132 \\
\hline Philippines & 25.012 & -27.875 & 4.471 \\
\hline Cote d'Ivoire & 10.067 & -24.188 & 1.101 \\
\hline South Africa & 16.61 & -24.182 & -2.816 \\
\hline Italy & 16.725 & -21.291 & -3.522 \\
\hline Argentina & 22.53 & -20.781 & 0.594 \\
\hline
\end{tabular}


The effect of net foreign assets on saving rate

\begin{tabular}{|c|c|c|c|}
\hline Egypt & 17.525 & -19.635 & -1.976 \\
\hline Indonesia & 33.373 & -14.781 & 0.797 \\
\hline Nigeria & 26.846 & -14.689 & 1.268 \\
\hline Republic of Congo & 25.531 & -7.312 & 5.065 \\
\hline Syrian Arab Republic & 20.89 & -3.422 & -3.308 \\
\hline Austria & 24.596 & 1.895 & 2.954 \\
\hline France & 18.556 & 3.376 & -1.743 \\
\hline Denmark & 22.683 & 14.269 & 5.506 \\
\hline Korea & 32.424 & 33.585 & 2.896 \\
\hline Finland & 20.885 & 43.757 & 1.432 \\
\hline Germany & 23.427 & 57.463 & 6.083 \\
\hline Botswana & 24.841 & 65.341 & -5.168 \\
\hline Belgium & 21.653 & 66.554 & 1.46 \\
\hline Sweden & 24.893 & 73.345 & 6.277 \\
\hline Japan & 23.314 & 80.073 & 3.569 \\
\hline Saudi Arabia & 37.607 & 80.372 & 14.808 \\
\hline Bahrain & 33.066 & 95.892 & 3.434 \\
\hline Malaysia & 32.915 & 96.168 & 11.499 \\
\hline Oman & 35.715 & 96.476 & 8.812 \\
\hline Netherlands & 25.246 & 148.572 & 6.569 \\
\hline Hong Kong SAR & 28.949 & 149.62 & 5.525 \\
\hline Trinidad and Tobago & 35.112 & 153.371 & 19.857 \\
\hline Algeria & 48.958 & 160.714 & 7.545 \\
\hline Venezuela & 26.85 & 160.804 & 4.878 \\
\hline Norway & 34.867 & 195.514 & 12.427 \\
\hline Taiwan Province of China & 32.401 & 208.867 & 9.269 \\
\hline Gabon & 36.37 & 244.188 & 9.061 \\
\hline United Arab Emirates & 28.487 & 301.218 & 3.069 \\
\hline Singapore & 46.54 & 322.865 & 24.412 \\
\hline Libya & 50.103 & 342.484 & 20.887 \\
\hline Kuwait & 48.703 & 559.427 & 29.643 \\
\hline Qatar & 56.748 & 744.938 & 26.331 \\
\hline
\end{tabular}




\section{Appendix 2}

Gross savings rate and foreign assets as percentage of GDP in 2010

\begin{tabular}{|c|c|c|}
\hline Country Name & saving & Net foreign assets \\
\hline New Zealand & 21.45339 & -44.6888 \\
\hline Greece & 7.315297 & -26.0401 \\
\hline Australia & 27.69843 & -23.4663 \\
\hline Latvia & 19.83488 & -16.4806 \\
\hline Portugal & 12.43516 & -10.6807 \\
\hline St. Lucia & 20.36088 & -10.3872 \\
\hline Estonia & 26.65565 & -10.0669 \\
\hline Spain & 20.82645 & -8.4051 \\
\hline Montenegro & -5.26694 & -4.70158 \\
\hline Belarus & 26.92417 & -1.28174 \\
\hline Bahamas, The & 12.50006 & -0.94068 \\
\hline Sudan & 24.18633 & -0.86675 \\
\hline Myanmar & 22.68732 & 0.01658 \\
\hline Slovenia & 23.18996 & 0.26605 \\
\hline United States & 11.50909 & 0.704036 \\
\hline Lithuania & 15.38073 & 0.900842 \\
\hline Romania & 25.08338 & 1.9074 \\
\hline Turkey & 14.40806 & 2.533677 \\
\hline Nicaragua & -0.7875 & 2.595323 \\
\hline Malawi & 8.167067 & 2.679123 \\
\hline Hungary & 24.90444 & 3.375747 \\
\hline Armenia & 9.17124 & 3.612507 \\
\hline Sri Lanka & 18.6525 & 4.216631 \\
\hline Georgia & 2.034217 & 4.323639 \\
\hline Italy & 18.48654 & 5.209486 \\
\hline Pakistan & 10.15377 & 5.626143 \\
\hline United Kingdom & 12.91013 & 5.917982 \\
\hline Dominican Republic & 4.729032 & 6.658624 \\
\hline Poland & 19.74442 & 7.142056 \\
\hline United Arab Emirates & 34.44901 & 7.179034 \\
\hline Chad & 12 & 8.055656 \\
\hline
\end{tabular}


The effect of net foreign assets on saving rate

\begin{tabular}{|c|c|c|}
\hline Colombia & 21.52231 & 8.09664 \\
\hline Venezuela, RB & 32.33607 & 8.247541 \\
\hline Zambia & 31.48323 & 8.612394 \\
\hline Azerbaijan & 51.89935 & 8.692297 \\
\hline Bangladesh & 17.80368 & 9.249327 \\
\hline Chile & 28.31894 & 9.468836 \\
\hline Mexico & 23.51948 & 10.19109 \\
\hline Lao PDR & 21.49966 & 10.39628 \\
\hline Kenya & 8.953688 & 10.56037 \\
\hline Brazil & 18.25583 & 10.87784 \\
\hline Vietnam & 28.60619 & 11.33007 \\
\hline Ghana & 14.92989 & 11.7578 \\
\hline Croatia & 22.87472 & 11.77969 \\
\hline Costa Rica & 16.8805 & 12.07682 \\
\hline Cote d'Ivoire & 18.44441 & 12.46657 \\
\hline Jamaica & 2.895242 & 12.60806 \\
\hline South Africa & 19.05885 & 12.67819 \\
\hline Sierra Leone & 3.324156 & 12.71346 \\
\hline Argentina & 25.30852 & 13.50285 \\
\hline Indonesia & 34.12176 & 13.5163 \\
\hline Gabon & 52.10808 & 13.7378 \\
\hline Guatemala & 3.777377 & 14.23893 \\
\hline Tunisia & 21.0449 & 14.56313 \\
\hline Ecuador & 20.50739 & 14.64688 \\
\hline Serbia & 6.328413 & 15.17186 \\
\hline El Salvador & -4.17682 & 15.30316 \\
\hline Japan & 21.37025 & 15.66604 \\
\hline India & 31.52593 & 15.99798 \\
\hline Senegal & 10.77067 & 16.156 \\
\hline Equatorial Guinea & 57.05925 & 16.67397 \\
\hline Gambia, The & 6.5 & 17.46529 \\
\hline Uganda & 13.47804 & 17.57861 \\
\hline Bosnia and Herzegovina & -1.32507 & 18.44654 \\
\hline Honduras & 2.21775 & 18.45324 \\
\hline Tanzania & 17.16311 & 18.84833 \\
\hline Nepal & 7.390787 & 20.60817 \\
\hline
\end{tabular}


Nissim Ben David

\begin{tabular}{|c|c|c|}
\hline Kazakhstan & 39.84637 & 20.62265 \\
\hline Cape Verde & 19.11957 & 20.75705 \\
\hline Korea, Rep. & 31.94211 & 20.81003 \\
\hline Swaziland & -2.29515 & 21.21813 \\
\hline Paraguay & 21.63303 & 21.90969 \\
\hline Syrian Arab Republic & 18.3888 & 22.01972 \\
\hline Angola & 28.03244 & 22.06535 \\
\hline Benin & 12.17729 & 22.3786 \\
\hline Namibia & 24.57689 & 23.12908 \\
\hline Moldova & -14.9786 & 23.13958 \\
\hline Macedonia, FYR & 6.777835 & 23.38326 \\
\hline Yemen, Rep. & 7.540357 & 23.54381 \\
\hline Tonga & -17.1733 & 23.89822 \\
\hline Denmark & 22.42872 & 24.05111 \\
\hline Peru & 27.28734 & 24.1997 \\
\hline Bulgaria & 23.0204 & 24.21588 \\
\hline Mozambique & 5.724723 & 24.53575 \\
\hline Morocco & 25.20587 & 25.20213 \\
\hline Egypt, Arab Rep. & 14.10575 & 25.29498 \\
\hline Czech Republic & 27.36069 & 27.09992 \\
\hline Albania & 3.947689 & 27.70447 \\
\hline Panama & 22.73904 & 29.84582 \\
\hline Iceland & 22.81976 & 30.65778 \\
\hline Afghanistan & -21.7924 & 30.97363 \\
\hline Haiti & -20.2011 & 31.11457 \\
\hline Guyana & -2.03899 & 31.61172 \\
\hline Philippines & 18.72782 & 31.82192 \\
\hline Uruguay & 19.81789 & 32.23292 \\
\hline Mongolia & 33.14273 & 32.54097 \\
\hline Russian Federation & 31.18261 & 33.47037 \\
\hline Sweden & 24.49533 & 34.08973 \\
\hline Netherlands & 26.14214 & 34.7108 \\
\hline Papua New Guinea & 20.58571 & 34.79103 \\
\hline Finland & 19.94647 & 35.33438 \\
\hline Cambodia & 11.9295 & 35.8889 \\
\hline Cyprus & 11.99943 & 36.80134 \\
\hline
\end{tabular}


The effect of net foreign assets on saving rate

\begin{tabular}{|l|c|c|}
\hline Malaysia & 39.22648 & 37.10227 \\
\hline Dominica & -0.40561 & 37.40393 \\
\hline Kosovo & -12.3424 & 38.5274 \\
\hline Congo, Rep. & 50.94492 & 39.09943 \\
\hline Switzerland & 30.58454 & 39.53693 \\
\hline Belgium & 22.89499 & 40.34596 \\
\hline France & 17.00667 & 43.17924 \\
\hline Thailand & 33.29735 & 48.29601 \\
\hline Jordan & -6.05141 & 50.12153 \\
\hline Botswana & 21.23956 & 52.05881 \\
\hline Bolivia & 23.8703 & 55.0676 \\
\hline China & 51.69536 & 56.16424 \\
\hline Germany & 22.8121 & 56.68331 \\
\hline Lesotho & -42.0569 & 63.32774 \\
\hline Ireland & 30.12621 & 64.16727 \\
\hline Austria & 25.95028 & 75.69826 \\
\hline Algeria & 50.73373 & 98.52624 \\
\hline Singapore & 51.89371 & 99.96196 \\
\hline Lebanon & 9.843946 & 103.6549 \\
\hline Saudi Arabia & 43.3622 & 108.0656 \\
\hline
\end{tabular}

Paper received: May $15^{\text {th }}, 2014$

Approved for publication: June $1^{\text {st }}, 2014$
Rad primljen: 15. maj 2014. Odobren za štampu: 1. jun 2014. 
Prof. Nissim Ben David, „Maks Štern“ akademski koledž, Emek Jezril, Izrael

\title{
EFEKAT STRANIH NETO SREDSTAVA U ODNOSU NA STOPU ŠTEDNJE
}

\begin{abstract}
S a ž e t a k
Posmatranjem empirijskih podatka dolazimo do zaključka da mnoge zemlje pokušavaju da odlože donošenje odluke o povećanju stope štednje kako bi izbegle smanjenje životnog standarda. Međutim odlaganje dovodi do pogoršanja finansijske stabilnosti zemlje.

Predstavljamo jednostavan teoretski model koji je veza između stopa štednje i strane neto imovine u zemlji. Koristeći presek podataka iz 135 zemalja u 2010. godini, uradili smo procenu matematičke statistike između, stopa štednje u 2010. godini, kao promenljivu variablu i dva pokazatelja variable: tekući račun u 2010. godine i grupisani tekući račun tokom 1980-2010. Nalazi pokazuju da industrijske zemlje lošeg finansijskog stanja imaju tendenciju da smanje iznos svojih stopa štednje kao spoljni dug, uzrokujući pogoršanje spoljnog duga, dok zemlje dobrog finansijskog stanja imaju tendenciju da povećavaju svoje stope štednje tako da finansijsko stanja postaje bolje. Samo u zemljama sa velikim spoljnim dugom, štedna stopa ima tendenciju rasta. Rezultati ukazuju da će bruto spoljni dugovi biti sve veći, što pogoršava svetsko finansijsko stanje i povećava rizik od globalne finansijske krize.
\end{abstract}

Ključne reči: strana sredstva, stope štednje, životni standard 